\title{
Islamic Political Thought in Indonesia in The Post-Truth Era
}

\author{
Jubair Situmorang ${ }^{1}$ \\ \{jubairsitumorang68@gmail.com ${ }^{1}$ \} \\ Institut Agama Islam Negeri (IAIN) Ternate, Indonesia ${ }^{1}$
}

\begin{abstract}
The political dilemma of Islam stems from the existence of fundamental problems in the political life of Muslims that are theological, such as the relationship between religion and politics in Islam. However, some are purely political, namely concerning the strategy of the political struggle itself in the complex background of Indonesian political life with multiple political interest groups. Until now, among Muslims, there are three courses regarding the relationship between Islam and politics. The first course stated that Islam is not merely a religion in the Western sense. The second course maintains that Islam is a religion in the Western term that has nothing to do with state affairs. The third course rejects the notion that Islam is a complete religion and furthermore that there is a constitutional system. These thoughts show a fundamental difference in the actualization of religious beliefs into political action. The marginalization of Islamic politics reached its peak with the enactment of a single principle which meant the weakening of Islamic political movements which were formalistic and legalistic and encouraged some of them to reformulate the meaning and strategy of Islamic politics further. With the narrowing of the room for movement for Islamic politics in a prim form, it is used as an opportunity to enter the political sphere through other avenues that are considering still very open. They think it is necessary to accommodate the government's idea to erode suspicion between Islam and the country. The reality of Islamic politics that is seen as failing to motivate Muslims, especially young intellectuals, is to seek new political formulations so that they can play a role in the country. One of them is reorienting the meaning of Islamic politics, which has been elaborated in legalistic and formalist styles. The post-truth era changes various paradigms because everything is seen situational, which is triggered by a lack of trust in science, social and economic inequality, and a decline in social capital. It means that facts as part of the truth or ignorance of the truth are lost and what develops is the blurring of the difference between the truth and the lies. This situation also occurs in political life in Indonesia, where the fact of the new political orientation is more towards substantive and integrative politics. It means that the new approach prioritizes the content of Islamic values as a source of inspiration for political activities as well as mutual acceptance and adjustment between Muslims and the country.
\end{abstract}

Keywords: Political Thought, Muslim, Post-truth 


\section{Introduction}

Substantially, Islamic politics is the confrontation of Islam with power and the country that creates political behavior and political culture oriented to Islamic values. The attitude of the behavior and political culture that uses Islamic adjectives stems from a moral and doctrinal concern for the integrity of the Islamic spiritual community [1].

In dealing with power and the country, political Islam in Indonesia is often in a dilemma. The dilemma faced concerns the tug-of-war between the demands for self-actualization as determinant as the majority group and the reality of political life which is not always conducive to selfactualization. As a consequence, political Islam is facing several strategic choices, and each of which has consequences in itself.

In the reform era, this phenomenon may repeat itself. The role of Islamic groups, both Islamic leaders and Islamic students in pushing the reform movement is very large. However, in subsequent developments, the reform movement was not always under the control of Islamic groups. The controllers of reform and national political life will be in the party or political interest group that controls the sources of political power. In modern times, the resources of political power are not only based on the times but also materials, ideas, and information.

The dilemma of Islamic politics is often exacerbated by the inability to get out of the dilemma itself. This thing is partly due to the lack of integration between political enthusiasm and political knowledge. High political morale that is not accompanied by extensive and in-depth knowledge of political developments often results in the neglect of strengthening political tactics and strategies. Two things are indispensable in practical politics and political games. The political dilemma of Islam stems from the existence of fundamental problems in the political life of Muslims that are theological, such as the relationship between religion and politics in Islam. However, some are purely political, namely concerning the strategy of the political struggle itself in the complex background of Indonesian political life with multiple political interest groups.

Islamic political pluralism is a reflection of the plurality of Islamic society. Meanwhile, the pluralism of the Islamic community itself is a logical consequence of the Islamization process in an archipelagic country, which differs in intensity from one place to another. In the context of relations between regions that were not easy in the past, it is possible to develop Islamic groups or organizations that have their characteristics and identities. The group which later crystallized into various organizations, apart from having a common point of view, they also has a specific cultural dimension that differentiates it from other Muslim groups. At some level, this cultural commitment has developed a sense of group solidarity among Muslims that overcomes their term of religious solidarity. The cultural dimension of various Islamic groups makes it difficult for them to unite in political life.

Political Islam in Indonesia in general has not succeeded in achieving political effectiveness. One of the bases for political effectiveness is leadership. The leadership of political parties has not been able to put into function the party as a medium for articulating the political interests of Muslims. There are at least three factors that cause this political ineffectiveness and other things 
can also be called the problems of political Islam. First, there is overestimation. Many Islamic party leaders are concerned about the power they have or the political affiliation of what is called the myth of humanity. Second, it is external, namely the intentional destruction of external political forces. Third, there are differences in views between party leaders regarding the relationship between religious beliefs and political action.

On top of that, the fundamental problem of Islamic politics is the difficulty in realizing unity, both on the scale between Islamic parties and on the scale of intra-one Islamic parties. Islamic parties are prone to conflict and party conflicts are prone to internal engineering.

These various problems must be able to be resolved by Islamic parties in the current reformation era. The existence of a complete amalgamation may not be realistic, except perhaps between Islamic parties originating from the same family. Another alternative available is a coalition so that only a few Islamic parties will participate in the elections. The presence of political parties serves to carry out the political continuity of a country and society [2].

The recent emergence of Islamic parties has generated a separate debate if it is not a matter of controversy. In the view of some circles, this phenomenon is seen as a manifestation of the reemergence of Islamic politics, or what is mistakenly termed "Islamic politicization". The first assessment is positive, because like other religions, Islam cannot be separated from politics. The second judgment, if the term is properly understood, it is negative. The term "politicization" (of anything) is always part of pejorative or manipulative engineering. You can imagine what would happen if this was imposed on something that had a divine nature (divine) such as Islam.

It is not known exactly what is meant by some who see the rise of Islamic political life today as a phenomenon that can be labeled Islamic politicization. However, if you look at the main indicator used as the basis for this assessment, namely the emergence of several political parties that use Islamic symbols and principles or which have major supporters of the Islamic community, it is not wrong to say that what is meant is the phenomenon of the re-emergence of Islamic political power. In the course of this thing that the possibility is always open to "politicize" the parts which form the basis of the ideology of these parties.

Nowadays among Muslims, there are three courses regarding the relationship between Islam and politics. The first course maintains that Islam is not merely a religion in the western sense, which only concerns the relationship between humans and God, and on the opposite that Islam is a religion that is perfect and complete with arrangements for all aspects of human life included state life.

The second course believes that Islam is a religion in the Western sense, which has nothing to do with state affairs. According to this tradition, the Prophet Muhammad was just an ordinary messenger like the previous apostles, with the sole task of inviting humans to return to a noble life by upholding noble character; and the Prophet never intended to establish and head a nation.

The third course rejects the opinion that Islam is a complete religion and that in Islam there is a constitutional system. But this school also rejects the notion that Islam is a religion in the Western sense which only regulates the relationship between humans and their Creator. This school maintains that Islam does not have a constitutional system, but there is a set of ethical values for state life. However, throughout the history that has been passed until now, it seems that 
Islamic political thought continues to run "in parallel" between integrated, symbiotic, and secularist.

The marginalization of Islamic politics reached its peak with the enactment of a single principle which also meant the weakening of Islamic political movements that were formalistic and legalistic, encouraging some of them to reformulate the meaning and strategy of Islamic politics further. With the narrowing of the space for political Islam in its formal form, it has become an opportunity to enter the political sphere through other avenues that are still considered very open. They think it is necessary to accommodate the government's idea to erode suspicion between Islam and the country. The reality of Islamic politics that is seen as failing to motivate Muslims, especially young intellectuals, is to seek new political formulations so that they can play a role in the country. One of them is reorienting the meaning of Islamic politics, which has been elaborated in legalistic and formalistic styles.

The post-truth era changes various paradigms because everything is seen situational, which is triggered by a lack of trust in science, social and economic inequality, and a decrease in social capital. As a result, facts as part of the truth or indifference to the truth are lost, which develops precisely the blurring of the differences between the truth and the lies [3].

This situation also occurs in political life in Indonesia, where the truth of the new political orientation is more towards substantive and integrative politics. It means that the new approach prioritizes the content of Islamic values as a source of inspiration for political activities as well as mutual acceptance and adjustment between Muslims and the country [4].

From the description above, the objective of this research is to analyze Islamic political thought in Indonesia in the post-truth era.

\section{Literature Review}

\subsection{The Typology of Islamic Political Thought}

The political history of the Indonesian Muslim community is an inseparable part of the political history of the Indonesian nation from the early decades of independence to the contemporary, even though not all Indonesian Muslim communities have fought for the aspirations of the Muslim community. This thing is inseparable from different understandings in interpreting the holistic nature of Islam.

There is an assumption that religion as a transcendental instrument in understanding the world, Islam is seen as not just a religion. Islam is often perceived as a comprehensive civilization, civil society, or associated with the religion and the country. The relationship between Islam and politics in Indonesia is like a sentimental journey because it involves fears of tense old hopes but still has to be discussed and carried out for various reasons and needs [5] .

Islamic teachings do not have to be formalized in the form of an Islamic state, but there is a certainty in the formation of a socio-political system that reflects conformity with Islamic values. 
The implementation that is emphasized is substantive, not formalistic. The political relationship between Islam and the country in Indonesia in its journey cannot be separated from the side of antagonism and confusion with one another. In social life, the relationship between religion and politics has a connection, but from different perspectives. On the one hand, society has a fundamental interest so that religion is not contaminated by political interests, because if religion is under political domination, religion will easily be misinterpreted and misused. Religion should be the direction and direction of how politics is carried out. It is not on the contrary that religion is legitimized to justify things that are contrary to humanitarian principles. Even religion is delegitimized as something that does not have any function in political life. As a result, religion is no longer a liberating force for various oppressions and injustices. On the other hand, religion can be misused and eventually develop into an oppressive and cruel power.

Broadly speaking, it can be divided into three paradigms, namely integral's, symbiotic, and secular. In the view of the integral political paradigm, religion and politics are united, where Islam is a religion that is perfect and complete with arrangements for all aspects of human life including political life and the country. Therefore, in-state, Muslims must return to the practice of the political life of Islamic state administration practiced by the Prophet Muhammad, and the four leaders (Khalifah). Should not imitate the constitutional system developed in a secular (western) country. In this paradigm perspective, political sovereignty is exercised based on divine authority because it originates and is in the hands of God [6].

Meanwhile, the symbiotic paradigm views that religion and politics have a reciprocal relationship that needs each other. In this case, religion needs the country because, with the country, religion can develop. On the other hand, the country also needs religion because state religion can develop in the guidance of spiritual ethics and morals. Up to this point, there is some caution not to emphasize the black-and-white relationship between Islam and politics.

The secular paradigm considers religion and politics to be two different entities, in which politics or the country did not make religion a specific instrument. In the Islamic context, this view rejects religious intervention or interference in political and constitutional matters. Religion is a private matter that has nothing to do with political activity [7].

From several studies, it is known that the typology of Islamic political thought in Indonesia as expressed by Bahtiar Effendi and M. Syafi'i Anwar as quoted by Din Syamsuddin - especially during the New Order era - formed at least three schools, namely: [8], namely formalistic, substantivistic and fundamentalism.

In the context of the explanation above, Bahtiar Effendy explained that there are at least two spectrums of political thought among Muslims. First, they think that Islam should be the basis of the state, shari'ah must be accepted as the state constitution, the concept of a nation-state is contrary to the concept of the ummah which knows no political and regional boundaries, and the concept of democracy is not the same as the syûra principles and others. His conception of thought is formalistic. The model of government or political power resides in one leader or caliphate which transcends geographic and demographic known as the nation-state concept. Second, the idea that Islam does not have a standard pattern of state theory or political system that must be implemented by Muslims [9]. 


\section{Methods}

This research is structured using a descriptive-analytical research method, where the authors take and focus attention on the problems that become research questions. The results of this study are then processed and analyzed for conclusions. This method aims to obtain objective exposure to a problem through the analysis process. Furthermore, the authors conducted a literature study. Library research itself is an activity of observing various literatures related to the subject matter discussed, whether in the form of books, journals, or writing that are helpful, so that it can be used as a source in research.

\section{Result and Discussion}

\subsection{The Development of Islamic Politics in Indonesia}

The change in the pattern of Islamic politics from the politics of formality to the politics of substantialize has implications for the development of Islamic politics in the next period. So that the politics of substantialize began to take root in Indonesian political culture, even though Islamic parties emerged fighting for political formality, but still the struggle for Islam as the state ideology would be increasingly difficult to realize because the secular ideology of Pancasila has taken root in the political system in Indonesia.

In the current context, it is complicated to say that an Islamic party is a forum for the aspirations of Muslims because Islamic parties are already fragmented. The tendency is now more towards the individual interests of Islamic politicians, not the interests of the ummah. So it can be said that the pattern of the Islamic party movement is moving towards a pragmatic direction.

Political figures (including Islamic politicians) both try to use religious symbols as a means of power struggle, sometimes cynically but generally through a rational process. When someone starts to realize that they are members of political groups colored by religious identity, and then the individual will assume that their interests are closely related to the welfare of their (ummah) religion. Such conditions are happening to the Islamic political elites today in Indonesia.

\subsection{The Prospect of Islamic Politics in Indonesia Viewed from the Relationship between Islam and the State in the Post Truth Era}

Islam is a monotheistic religion that was spread by the Prophet Muhammad SAW. Al Quran and Sunnah are sources or guidelines for people to carry out social and political relations. Thus, Muslims generally believe in the holistic nature of Islam as a divine instrument for understanding the world. Islam is often seen as more than just a religion, for that view states that Islam does not recognize the dividing wall between the spiritual and the temporal, but rather regulates all aspects of life.

Meanwhile, the Country has the power to force and the State is an autonomous entity such as institutions and institutions. It could be said that the State is something that is far away, even 
foreign, the most distant collection of humans that can easily turn into hostile relations. [10]. It means that the Country can use coercive force for the interests of certain parties, and the Country may be used by political elites for personal gain.

The problem now is how we can provide a suitable meeting point for the relationship between Islam and the State in Indonesia. First, it is recognized that long before this country was formed and independent, Islam was present as a very dominant factor in political life, with the existence of Islamic kingdoms, such as the Islamic sultanate. So, long before Indonesia existed, there was already an Islamic power in the form of a kingdom and a sultanate that had implemented Islamic law as state law in several matters, such as marriage, inheritance, and others. Islam and politics cannot be separated, because a person's political behavior is influenced by religion. But Islam can be separated in the sense that the country must be neutral towards religion where the country is not hostile or supportive of a particular religion.

The first is an accommodative strategy of justification for state power that often does not reflect Islamic idealism with the consequence of accepting blasphemy from "hardline" Muslims. The second is an isolative-oppositional strategy, namely rejecting and separating from state power to build its strength, with the consequence of losing its supporting factor, namely the power of the state itself, which is then controlled and utilized by other parties. The third is an integrativecritical strategy, namely integrating oneself into state power, but still being critical of the abuse of power in a struggle from within. However, this strategy is often faced with the hegemony of the state itself, so that the effectiveness of its struggle is questioned.

\subsection{The Reformulation of Indonesian Islamic Politics}

When the marginalization of Islamic politics reached its peak with the enactment of a single principle, which meant the weakening of Islamic political movements that were formalistic and legalistic, prompted some of them to reformulate the meaning and strategy of Islamic politics further. With the narrowing of the space for political Islam in the formal form, it can be used as an opportunity to enter the political sphere through other avenues that are considered still very open. They think it is necessary to accommodate the government's idea to erode suspicion between Islam and the country. The reality of Islamic politics that is seen as failing to motivate Muslims, especially young intellectuals, is to seek new political formulations so that they can play a role in the country. One of them is reorienting the meaning of Islamic politics, which has been elaborated in legalistic and formalist styles. The new political orientation is more towards substantive and integrative politics. It means that the new approach prioritizes the content of Islamic values as a source of inspiration for political activities as well as mutual acceptance and adjustment between Muslims and the country.

It is not easy to unite perceptions among Muslims, because internally, there are differences of opinion on how to bridge political relations (Islam) with the country. The debate continues today to the two poles. A first pole is a group that wants a formal link between Islam and the country either in the form of an Islamic state or a state that applies Islamic teachings. A second pole is a group that strongly opposes the connection between Islam and the country in any form because the two are formally and substantially different [11]. Regardless of different perspectives, Islamic

political ideas in their development have given Muslims a new awareness of a country that is more 
oriented towards functioning Islamic values to solve social problems such as ignorance, poverty, unemployment, and social and economic underdevelopment.

Such a paradigmatic shift in Islamic politics makes the political framework of the flow, namely politics based on the tendency of the level of religious appreciation and practice to be no longer relevant to explain the constellation and dynamics of Islamic politics in Indonesia. The fact is that the groups categorized by Geertz as santri do not choose and support political parties that are based on Islam or labeled Islam. The political strategy developed by Islamic political thinkers in the post-truth era today is more inclusive, integrative, and diversified. During its development, the change in the paragraph on Islamic politics had an impact on the pattern of relations between Islam and the country which began to melt away, becoming more accommodative and integrative. It is not surprising that the Islamic santri group now does not only use parties labeled Islam as a vehicle for articulating the constructed political paradigm. The truths that have been received so far are automatically deconstructed when the facts of people's lives are no better. Post-truth politics makes the truth accepted so far considered a justification for untruth, but is indoctrinated as Islamic teachings, and this situation has led to this new political orientation more towards substantive and integrative politics. It means that the new approach prioritizes the content of Islamic values as a source of inspiration for political activities as well as mutual acceptance and adjustment between Muslims and the country.

\section{Conclusion and Implications}

Islamic political thought in Indonesia has had up and down, and it starts from symbolist to substantive, this thing has happened because of the breadth of Islam that can be understood from various points of view. So it is not uncommon for clashes between Islam on the one hand and the country on the other. The post-truth era has resulted in the emergence of a new paradigm, where post-truth justification creates a new, more substantial awareness that is no longer dichotomist. Even though at the same time political ideas of division between Islam and the country have emerged, but more for a moment that occurred during the general election or regional head election.

\section{References}

[1]Abdullah, Taufiq.: Islam danMasyarakat. Jakarta: PantulanSejarah Indonesia (1987)

[2] bhihara, Abu Bakar.: Pengantar Ilmu Politik. Jogyakarta: Ar-Ruzz Media (2010)

[3] Kalpokas, I.: A Political Theory of Post-truth, Switzerland: Palgrave Macmillan (2019)

[4]Jamhari (ed.).: EnsiklopediTematisDunia Islam: DinamikaMasakini (Islam Indonesia). Jakarta: IchtiarBaruVanHoeve (2002)

[5]Al-Bahnasawi, Salim Ali.: Wawasan Sistem Politik Islam. Jakarta: Pustaka Al-Kautsar (2006)

[6]Hering, B.B. (ed.).: Studies on Indonesia. Townsville: Center for Southeast Asian Studies, James Cook University (1989)

[7]Jamhari (ed.).: Ensiklopedi Tematis Dunia Islam: Dinamika Masakini (Islam Indonesia). Jakarta: IchtiarBaruVanHoeve (2002) 
[8]Situmorang, J.: Model Pemikiran \& Penelitian Politik Islam. Bandung: Cv. PustakaSetia (2014)

[9]Keyes, R.: The Post-truth Era: Dishonesty and Deception in Contemporary Life. New York: St. Martin's Press (2004)

[8]Piscatori, James P. (ed.).: Islam in the Political Process. New York: Cambridge University Press (1983)

[9]William Liddle, R.: Pemilu-Pemilu Orde Baru: Pasang Surut Kekuasaan Politik. Jakarta: Grafiti (1985)

[10]Surwndono.: Pemikiran Politik Islam. Yogyakarta: LPPI UMY (2001) 